\title{
Acoustic observations of dusky dolphins Lagenorhynchus obscurus hunting Cape horse mackerel Trachurus capensis off Namibia
}

\author{
Matteo Bernasconi ${ }^{1,2, *}$, Leif Nøttestad ${ }^{1}$, Bjørn Erik Axelsen ${ }^{1}$, Jens-Otto Krakstad ${ }^{1}$ \\ ${ }^{1}$ Institute of Marine Research, PO Box 1870 Nordnes, 5817 Bergen, Norway \\ ${ }^{2}$ Pelagic Ecology Research Group, Scottish Oceans Institute, University of St Andrews, St Andrews KY16 8LB, UK
}

\begin{abstract}
Predator-prey interactions of mammals and their fish prey in marine ecosystems are rarely identified and recorded. We document for the first time the underwater behaviour of hunting dusky dolphins Lagenorhynchus obscurus and the responses of their prey, Cape horse mackerel Trachurus capensis, observed in open ocean waters off northern Namibia. Predator-prey interactions were monitored acoustically during a continuous period of $2 \mathrm{~h}$ with a split-beam scientific echo sounder, and the surface behaviour of the dolphins was observed from the ship's deck. In total 54 predator-prey events were observed (mean, 0.45 events min $^{-1}$ ). The maximum burst speed during attack was $9.9 \mathrm{~m} \mathrm{~s}^{-1}$, while the average attack speed was $3.4 \mathrm{~m} \mathrm{~s}^{-1}$ (mean swimming speed: $1.4 \mathrm{~m} \mathrm{~s}^{-1}$ ). Dolphin traces were predominantly located underneath the fish aggregation (63\% of the time), as the dolphins attacked the schools from underneath (mean depth: $120 \mathrm{~m}$; maximum depth: $156 \mathrm{~m}$ ). The dolphin target strength at $38 \mathrm{kHz}$ was, on average, $-31.5 \mathrm{~dB}$ ( $95 \% \mathrm{CI}-33.4$ to $-30.2 \mathrm{~dB}$ ). The attacks caused immediate reactions in the Cape horse mackerel aggregations: subschools were forced towards the surface where they were herded into dense aggregations by the dolphins. Observed predator response patterns included 'Vacuole' $(\mathrm{n}=21)$, 'Split' $(\mathrm{n}=19)$, 'Bend' $(\mathrm{n}=10)$ and 'Hourglass' $(\mathrm{n}=4)$. Packing densities changed significantly before $\left(0.4 \mathrm{fish}^{-3}\right)$, during $\left(2.0\right.$ fish $\left.\mathrm{m}^{-3}\right)$ and after $\left(0.3\right.$ fish $\left.\mathrm{m}^{-3}\right)$ the dolphin attacks, and when predators burst into the fish aggregations, mean $( \pm \mathrm{SD})$ intraschool packing densities of horse mackerel were significantly lower in front of the predators

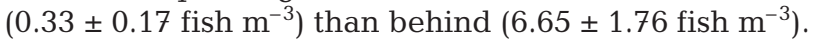

KEY WORDS: Dusky dolphin - Lagenorhynchus obscurus · Cape horse mackerel - Trachurus capensis · Feeding behaviour $\cdot$ Ecology $\cdot$ Predator-prey interactions $\cdot$ Acoustics $\cdot$ Target strength

\section{INTRODUCTION}

The Benguela current system is one of the world's 4 major western boundary upwelling regions (Fig. 1) and has historically been considered one of the most productive marine ecosystems in the world (Shannon 1985). In the south it borders the Agulhas Bank region in South Africa at about $35^{\circ} \mathrm{S}$, while the northern border of the system is the Angola-Benguela frontal zone between $14^{\circ} \mathrm{S}$ and $17^{\circ} \mathrm{S}$ (Shannon \& Nelson 1996). The Benguela Current Large Marine Ecosystem (BCLME) is one of the largest wind-driven coastal upwelling systems in the world (Shannon \& O'Toole 2003).
Cape horse mackerel Trachurus capensis is currently the most abundant commercial species within the northern BCLME, and as an important predator and prey it plays a key ecological role in the ecosystem (Boyer \& Hampton 2001). Abundance estimation of horse mackerel is primarily done by identification of acoustic targets and ground-truthing by pelagic trawling (Axelsen et al. 2004, Vaz Velho et al. 2006). Cape horse mackerel is known to exhibit considerable vertical migrations that have been adapted to the prevailing local conditions (e.g. Pearre 2003, Vaz Velho et al. 2010). In the southern BCLME, Cape horse mackerel 


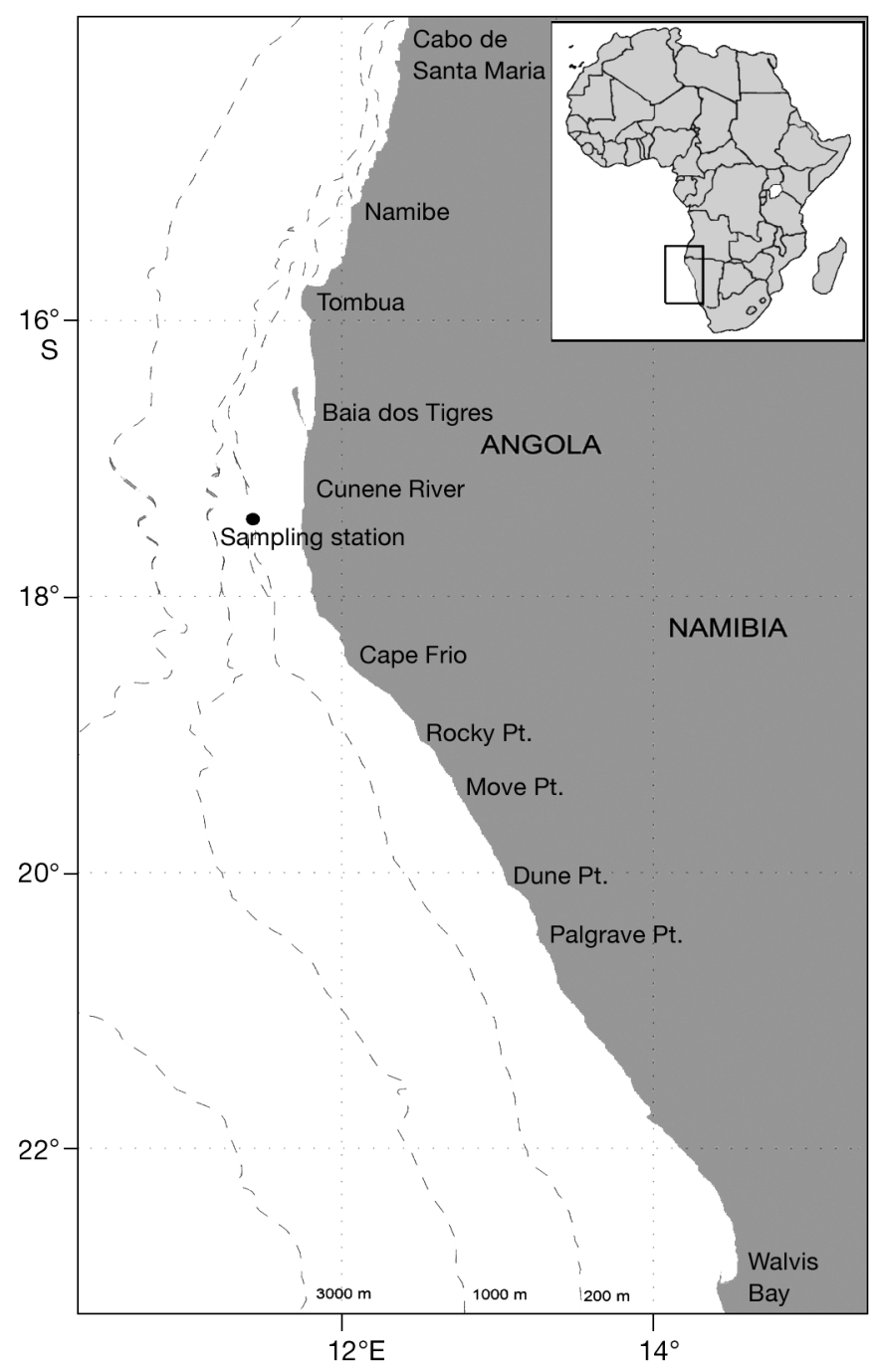

Fig. 1. Study area (black dot) off the coast of northern Namibia in the Benguela Current Large Marine Ecosystem (BCLME), which is off southern Angola, Namibia and South Africa (west coast). Inset shows location of study area in Africa

generally form dense shoals in midwater or close to the bottom during the day, and they migrate to midwater at night and disperse before aggregating and descending again at dawn (Pillar \& Barrange 1998). Although more variable, a similar pattern has been found for the northern BCLME, where Cape horse mackerel typically remain in midwater during the day and ascend to near the surface at night (Axelsen et al. 2004).

Top predators such as dolphins often target schooling pelagic fish as their main prey, thereby affecting their behaviour, distribution and abundance (e.g. Perrin et al. 2002). Protection against predators at the individual level is one of the primary functions of schooling (Pitcher \& Parrish 1993), and predator attacks may considerably affect internal school structure and density (Pitcher \& Wyche 1983, Hall et al. 1986, Similä \&
Ugarte 1993, Vabø \& Nøttestad 1997, Nøttestad \& Axelsen 1999, Axelsen et al. 2000, 2001, Nøttestad et al. 2002a,b). Studying school-level prey responses to predator attacks is thus necessary to better understand the nature of prey-predator interactions (Pitcher \& Wyche 1983, Kenney et al. 1997, Axelsen et al. 2001). Animal energetic fitness can be substantially affected by foraging decisions, because the amount of food that an animal can obtain has a major influence on its survival in the wild (Beyer 1995). Moreover, group foraging may increase survival probabilities, not necessarily by increasing the overall feeding rate, but rather by decreasing its variance (Thompson et al. 1974, Clark \& Mangel 1984). When studying predator-prey interactions in nature, quantifying predator attack rates and the corresponding rates of school response events are essential to understand the behaviour causing the observed school dynamics (Axelsen et al. 2001), and hydroacoustics have proven to be a powerful tool for these types of quantifications (Nøttestad \& Axelsen 1999, Axelsen et al. 2001, Nøttestad et al. 2002a, Benoit-Bird et al. 2004).

While some knowledge exists on the behaviour of Cape horse mackerel (e.g. Axelsen et al. 2004), the behaviour of dusky dolphin Lagenorynchus obscurus in this area of the world has only rarely been investigated (Van Waerebeek \& Würsig 2009). Dusky dolphins are widespread in the southern hemisphere, but their distribution is probably discontinuous (Van Waerebeek \& Würsig 2009). They are found along the coast of Southern Africa from Lobito in southern Angola to Cape Agulhas in Cape Province; however, little information is available on the relative abundance of $L$. obscurus within its distribution range (Jefferson et al. 2008). Dusky dolphins are usually found over the continental shelf and slope (Aguayo et al. 1998, Jefferson et al. 2008), and their distribution within the BCLME is primarily associated with the cold waters of the Benguela Current along the west coast of South Africa. Dusky dolphins are gregarious animals, with average observed group sizes varying from 6 to about 300 individuals, with regular, stable subgroups (Würsig \& Würsig 1980). Dusky dolphin underwater behaviour was studied by Würsig (1982) and more recently by Benoit-Bird et al. (2004), who used a fish finder to evaluate the dolphin's relative abundance by linking relatively strong target detections presumed to be dolphins with the presence of deep scattering layers of its schooling prey. While interaction processes between dusky dolphins and their prey during predation events have been documented in other parts of the world (Vaughn et al. 2007, 2010), there are no previous reports from African waters.

The main aims of the present study were to document predator-prey interactions between dusky dol- 
phins and Cape horse mackerel in situ, and to quantify attack rates, diving speeds and depths of attacking dolphins along with corresponding school response events and changes in school structure and packing densities of the schooling prey. These were accomplished by the use of high-resolution, calibrated echosounder data, thus taking advantage of the large sampling volumes and high spatial and temporal resolutions offered by the hydroacoustic method. Parallel visual surface observations and targeted pelagic trawling served to verify the presence of the dolphins and the horse mackerel at the study site, as well as to obtain biological samples of the populations under study.

\section{MATERIALS AND METHODS}

The data presented were collected during a fisheries acoustic survey with the RV 'Dr. Fridtjof Nansen' in Namibia. Predator-prey interactions reported were observed in northern Namibia, near the border to Angola $\left(17^{\circ} 24^{\prime} \mathrm{S}, 11^{\circ} 29^{\prime} \mathrm{E}\right)$, on 23 September 2002 between 10:00 and 12:00 h (UTC). The bottom depth in the area was about 160 to $180 \mathrm{~m}$. Acoustic data were logged throughout the observation period with a $38 \mathrm{kHz}$ calibrated scientific echosounder (Simrad EK500) (Foote 1987) while the vessel drifted passively over the aggregations at low speed (1 to 2 knots). The acoustic data were logged and analyzed with Echolog/ Echoview v. 3.40 software (Myriax Software ${ }^{\circledR}$ ). The presence of the submerged dolphins observed acoustically in the water column was verified by visual observations of the dolphins when they were at the surface before and after diving. The visual observations were done at close range $(10$ to $50 \mathrm{~m}$ ) from the ship's main deck, located about $10 \mathrm{~m}$ above sea level, and were recorded with a camcorder. Biological samples of Cape horse mackerel were obtained by means of targeted pelagic trawling with a pelagic sampling trawl (Åkrehamn, about $15 \mathrm{~m}$ vertical opening). Oceanographic data were sampled by means of a CTD probe (Seabird) submerged to near the bottom immediately before and after the acoustic observations were made. A weather station onboard the research vessel recorded data on wind stress, solar irradiance and wave conditions at the study site.

Dolphin behaviour. Candidate dolphin traces were first identified by manual scrutiny of the volume backscattering strength (Sv) echograms (Simmonds \& MacLennan 2005). Dolphin traces were subsequently verified by means of single target tracking according to the following criteria: minimum number of detections per trace: 6 ; maximum number of missed detections per trace: 2; maximum distance between consecutive detections within each trace: $5 \mathrm{~m}$; and maximum aspect angle from acoustic axis: $5^{\circ}$. For each acoustic dolphin trace, the horizontal and vertical position of the dolphin, the mean compensated target strength $(\mathrm{TS}, \mathrm{dB})$, the mean and maximum withintrace swimming speed $\left(\mathrm{m} \mathrm{s}^{-1}\right)$ and the mean and maximum swimming depths $(\mathrm{m})$ were measured. Selected traces were plotted in 3 dimensions (3D) for visualization of the dolphin swimming pattern (Fig. 2). The risk of misinterpreting large fish for dolphins was further diminished by inspection of the trend in the variation of the TS detections, which were consistent with the dorso-ventral swimming pattern typical for cetaceans (Fig. 3) (Love 1973, Au 1996, Miller et al. 1999, BenoitBird et al. 2004, Au et al. 2007, Lucifredi \& Stein 2007, Bernasconi et al. 2009). All computations on TS were carried out in the linear domain.

Predator response reactions. The predator response reactions were readily identified by visual inspection of the echograms in terms of the presence of dolphin traces and associated response patterns in the fish layer. First, attack and nonattack situations were defined and polygons drawn along the perimeter of the schools. All school response events were then recorded and classified as 'Split' (fragmentation of the school), 'Bend' (inflection of the school), 'Vacuole' (an empty space created in the centre of the school) or 'Hour-

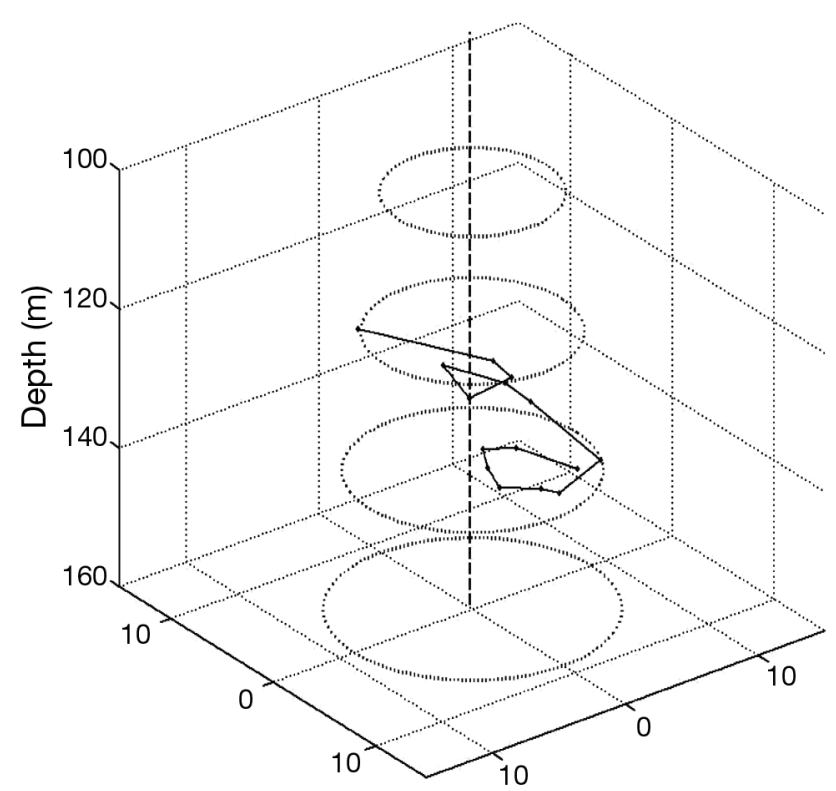

Distance from the transducer axis $(\mathrm{m})$

Fig. 2. Lagenorhynchus obscurus. Three-dimensional plot showing the trace of an individual dusky dolphin (the filled points are single target detections; the fitted, solid line represents the projected movements) spanning from 132.6 to $136.1 \mathrm{~m}$ depth. The dotted circles indicate the $-3 \mathrm{~dB}$ beam width by depth, corresponding to a $14.3 \mathrm{~m}$ diameter or $160 \mathrm{~m}^{2}$ area at the beamfront at $160 \mathrm{~m}$ range. The observation was made immediately underneath the Cape horse mackerel layer 

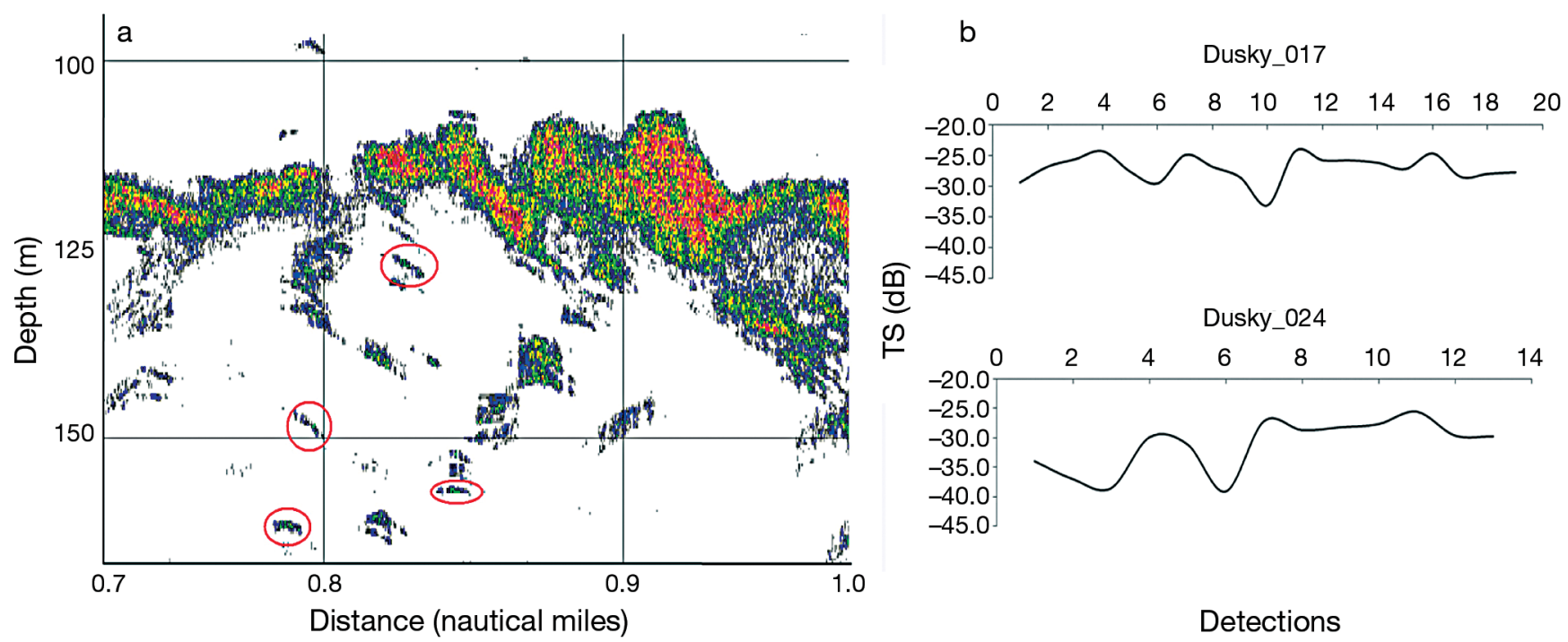

Fig. 3. Lagenorhynchus obscurus. (a) Volume backscattering strength (Sv) (dB) echogram showing the Cape horse mackerel layer with dolphins (encircled) located underneath the school and (b) target strength (TS) (compensated) detections for 2 individual dusky dolphin target traces

glass' (a constriction in the centre of the school) (Nøttestad \& Axelsen 1999). Attack-response scenarios were standardized to observation periods corresponding to sailed distances of 0.5 nautical miles (nmiles) and aggregated into the following subsections: before, during and after the dolphin attack. The observation periods were further divided into integrator bins of 0.1 nmile (185.2 m) horizontally by $25 \mathrm{~m}$ vertically. The volume densities were then integrated over the integrator bins producing acoustic backscattering coefficient $s_{A}\left(\mathrm{~m}^{2} \mathrm{nmile}^{-2}\right)$ (MacLennan et al. 2002). The fish volume fish densities $\left(\rho_{\mathrm{v}}\right.$, fish $\left.\mathrm{m}^{-3}\right)$ were then calculated according to:

$$
\rho_{\mathrm{v}}=\frac{s_{A}}{\left\langle\sigma_{\mathrm{bs}}\right\rangle \cdot 1852^{2} \cdot \Delta z}
$$

where $s_{A}$ is the acoustic backscattering coefficient in $\mathrm{m}^{2}$ nmile $^{-2}, \Delta z$ the corresponding depth interval over which the acoustic data were integrated, and $\left\langle\sigma_{b s}\right\rangle$ the mean estimated acoustic backscattering cross-section of the fish, relating to the fish TS by:

$$
\left\langle\sigma_{\mathrm{bs}}\right\rangle=4 \pi \cdot 10^{\overline{\mathrm{TS}} / 10}
$$

Assuming that the mean TS of the Cape horse mackerel did not change during the attacks scenarios, the mean TS was estimated according to Peña (2004):

$$
\overline{\mathrm{TS}}=20 \cdot \log _{10} L-66.0
$$

where $L$ is the mean total length of the Cape horse mackerel as determined from the trawl samples $(17.0 \mathrm{~cm}$, thus corresponding to an average TS of $-41.4 \mathrm{~dB})$.
To investigate the effect of the attacking predators on the local packing densities within the layer, the volume backscattering strength $(\mathrm{Sv}, \mathrm{dB})$ and the acoustic backscattering cross-section $\left(s_{A}, \mathrm{~m}^{2} \mathrm{nmile}^{-2}\right)$ for small subsections of the school immediately in front of and immediately behind the predators entering into the fish layer were extracted, converted to fish densities according to Eq. (1) and then compared.

\section{RESULTS}

During the observation period the weather conditions were favourable, with partial cloud cover (mean sun radiation: $281.5 \mathrm{~W} \mathrm{~m}^{-2}$ ), light southwesterly winds (mean wind speed: 5.8 knots $=2.98 \mathrm{~m} \mathrm{~s}^{-1}$ ) and a calm sea (wave height: 0.5 to $1.0 \mathrm{~m}$ ). The temperature and salinity were stable throughout the water column, with approximately $16^{\circ} \mathrm{C}$ temperature at the surface, decreasing to about $15^{\circ} \mathrm{C}$ at $100 \mathrm{~m}$ depth, and salinity of $35.5 \mathrm{psu}$ throughout the water column. Surface waters were well oxygenated (about $5 \mathrm{ml} \mathrm{l}^{-1}$ dissolved oxygen), dropping to about $3 \mathrm{ml} \mathrm{l}^{-1}$ at $75 \mathrm{~m}$ and about $1 \mathrm{ml} \mathrm{l}^{-1}$ below $100 \mathrm{~m}$ depth.

The dolphins were most often located underneath the fish aggregation (63\% of the time) rather than above the fish aggregations (37\%) (whenever they were not located within the layer). The dolphins dove to a maximum recorded diving depth of $156 \mathrm{~m}$ (mean recorded depth, $120 \mathrm{~m}$ ) in an area where seabed depth was $177 \mathrm{~m}$. Mean attack speed was estimated at $3.4 \mathrm{~m}$ $\mathrm{s}^{-1}$, while the maximum recorded attack speed (burst 
speed) was $9.9 \mathrm{~m} \mathrm{~s}^{-1}$, which was recorded at $125 \mathrm{~m}$ depth as the tracked dolphin penetrated inside the school (21 single target detections were recorded within this trace). The mean overall swimming speed was $1.4 \mathrm{~m} \mathrm{~s}^{-1}$. Swimming speeds and depths are summarized in Table 1.

The mean recorded TS for the dusky dolphins at $38 \mathrm{kHz}$ was $-31.5 \mathrm{~dB}(95 \% \mathrm{CI}:-33.4$ to $-30.2 \mathrm{~dB}$; range: -39.9 to $-22.7 \mathrm{~dB}$ ) (Fig. 4). An example of a dolphin trace obtained underneath the horse mackerel layer is shown in 3D in Fig. 2, which illustrates the dolphin encircling behaviour underneath the school.

Example of echograms before, during and after attack-response scenarios and histograms of total $s_{A}$ by depth intervals are shown in Fig. 5, while the corresponding fish volume packing densities are shown in Fig. 6. Initially, before the dolphin attacks, the horse mackerel were predominantly aggregated in a horizontally extended layer at 100 to $125 \mathrm{~m}$ depth with a vertical distribution of the main layer being approximately $20 \mathrm{~m}\left(0.7\right.$ fish $\left.\mathrm{m}^{-3}\right)$. The mean $s_{A}$ for the undisturbed situation was $2275 \mathrm{~m}^{2}$ nmile $^{-2}$ (Fig. 5a), corresponding to 0.4 fish $\mathrm{m}^{-3}$. During the attacks the horse mackerel aggregation split into 2 far more distorted main fractions, with the larger of the components moving towards the upper pelagic (approximately $50 \mathrm{~m}$ vertical extension) and the other remaining at the same depth (30 to $40 \mathrm{~m}$ vertical extension). The shape of both school components immediately changed, becoming highly amorphous (Fig. 5b). The fish thus concentrated in the top layer of the water column (25 to $50 \mathrm{~m}: 2.6$ fish m${ }^{-3} ; 50$ to $75 \mathrm{~m}: 1.4$ fish m${ }^{-3} ; 75$ to $100 \mathrm{~m}$ : 0.8 fish $\mathrm{m}^{-3}$ ), and the mean $s_{A}$ increased to $12440 \mathrm{~m}^{2}$ nmile $^{-2}$, or 2.0 fish $\mathrm{m}^{-3}$. After the attacks, the horse mackerel reorganized as a 'regular' (undisturbed) daytime school aggregation at 100 to $150 \mathrm{~m}$ depth (100 to $125 \mathrm{~m}: 0.5$ fish $\mathrm{m}^{-3} ; 125$ to $150 \mathrm{~m}: 0.1 \mathrm{fish} \mathrm{m}^{-3}$ ), and the mean $s_{A}$ decreased to $1883 \mathrm{~m}^{2} \mathrm{nmile}^{-2}\left(0.3\right.$ fish $\left.\mathrm{m}^{-3}\right)$ for the postattack period (Fig. $5 \mathrm{c}$ ). The mean packing densities before, during and after attacks were significantly different (ANOVA Type II Wald test: $\mathrm{p}<0.01$ ).

Altogether 54 predator response events were observed throughout the observation period, corresponding to 0.45 events $\min ^{-1}$ on average (Table 2). The

Table 1. Lagenorhynchus obscurus. Swimming speeds and depths of the tracked dusky dolphins (35 traces, 385 detections)

\begin{tabular}{|c|c|c|c|c|}
\hline \multirow[t]{2}{*}{ Statistic } & \multirow{2}{*}{$\begin{array}{l}\text { Detections } \\
\text { per trace }\end{array}$} & \multirow{2}{*}{$\begin{array}{l}\text { Depth } \\
(\mathrm{m})\end{array}$} & \multicolumn{2}{|c|}{ Swimming speed $\left(\mathrm{m} \mathrm{s}^{-1}\right)$} \\
\hline & & & Mean & Max. \\
\hline Min. & 6 & 42.2 & 0.6 & 1.6 \\
\hline Max. & 21 & 156.0 & 2.3 & 9.9 \\
\hline Mean & 11 & 120.3 & 1.4 & 3.4 \\
\hline SD & \pm 5.1 & \pm 28.3 & \pm 0.4 & \pm 1.6 \\
\hline CV (\%) & 45.1 & 23.5 & 32.5 & 46.4 \\
\hline
\end{tabular}

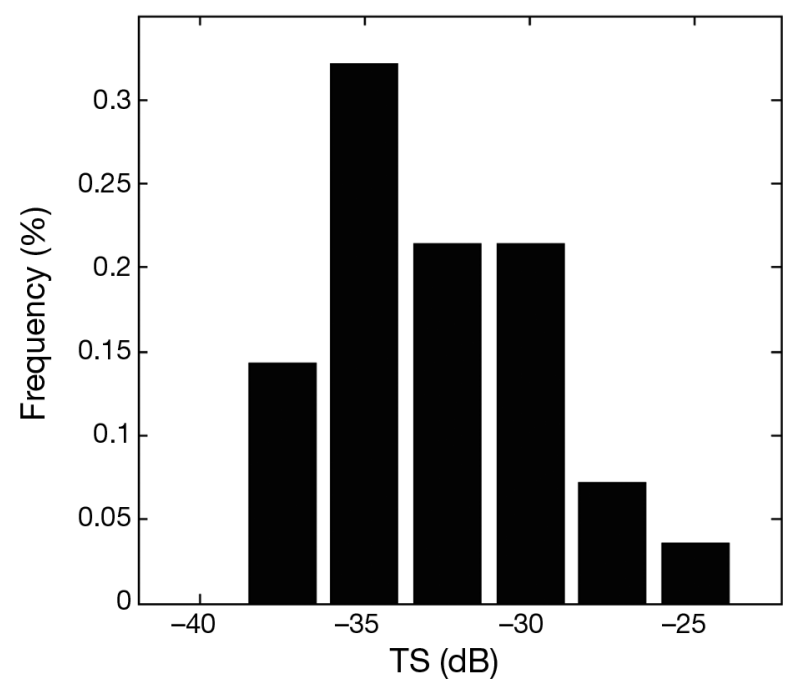

Fig. 4. Lagenorhynchus obscurus. Frequency distribution of the recorded compensated target strength (TS) at $38 \mathrm{kHz}$ for dusky dolphin (35 traces, 390 single detections). The mean overall TS was $-31.5 \mathrm{~dB}$ (range: -39.9 to $-22.7 \mathrm{~dB}$; $95 \% \mathrm{CI}$ : -33.4 to $-30.2 \mathrm{~dB}$ )

most common response pattern was Vacuole $(\mathrm{n}=21)$, followed by Split $(n=19)$, Bend $(n=10)$ and Hourglass $(\mathrm{n}=4)$. Attacked schools had, on average, 4.6 times higher packing densities than did unattacked schools (Table 3). An example of a Vacuole formation as a dolphin enters into the fish aggregations is shown in Fig. 7a. The avoidance of individual fish can be seen as locally reduced mean $( \pm \mathrm{SD})$ packing densities in front of (mean Sv: $-57.2 \mathrm{~dB}, 95 \% \mathrm{CI}$ : -58.6 to $-56.1 \mathrm{~dB}$; or $0.33 \pm 0.17$ fish $\mathrm{m}^{-3}$ ) and to the sides of the predator where the fish avoided the predator, and increased packing densities behind the predator (mean Sv: $-44.1 \mathrm{~dB}, 95 \% \mathrm{CI}:-44.8$ to $-43.6 \mathrm{~dB}$; or $6.65 \pm 1.75 \mathrm{fish}$ $\mathrm{m}^{-3}$ ) (Fig. 7b), where they rejoined. The packing densities in front of and behind the predator were significantly different (Welch 2 -sample $t$-test, $\mathrm{p}<0.01$ ).

\section{DISCUSSION}

We have for the first time documented dusky dolphins diving down to depths of $156 \mathrm{~m}$ (mean: $120 \mathrm{~m}$ depth). Previous studies have reported diving depths of up to $135 \mathrm{~m}$ (Benoit-Bird et al. 2004). In the present study, groups of 10 to 20 hunting dolphins were found to have major effects on the swimming behaviour, structure, density and depth of schooling Cape horse mackerel. The dolphins forced the horse mackerel towards the surface (25 to $50 \mathrm{~m}$ depth), thereby making the mackerel easier to prey upon (Nøttestad et al. $2002 b)$. This type of cooperative behaviour, to dive underneath schools, force the prey into a tight ball 

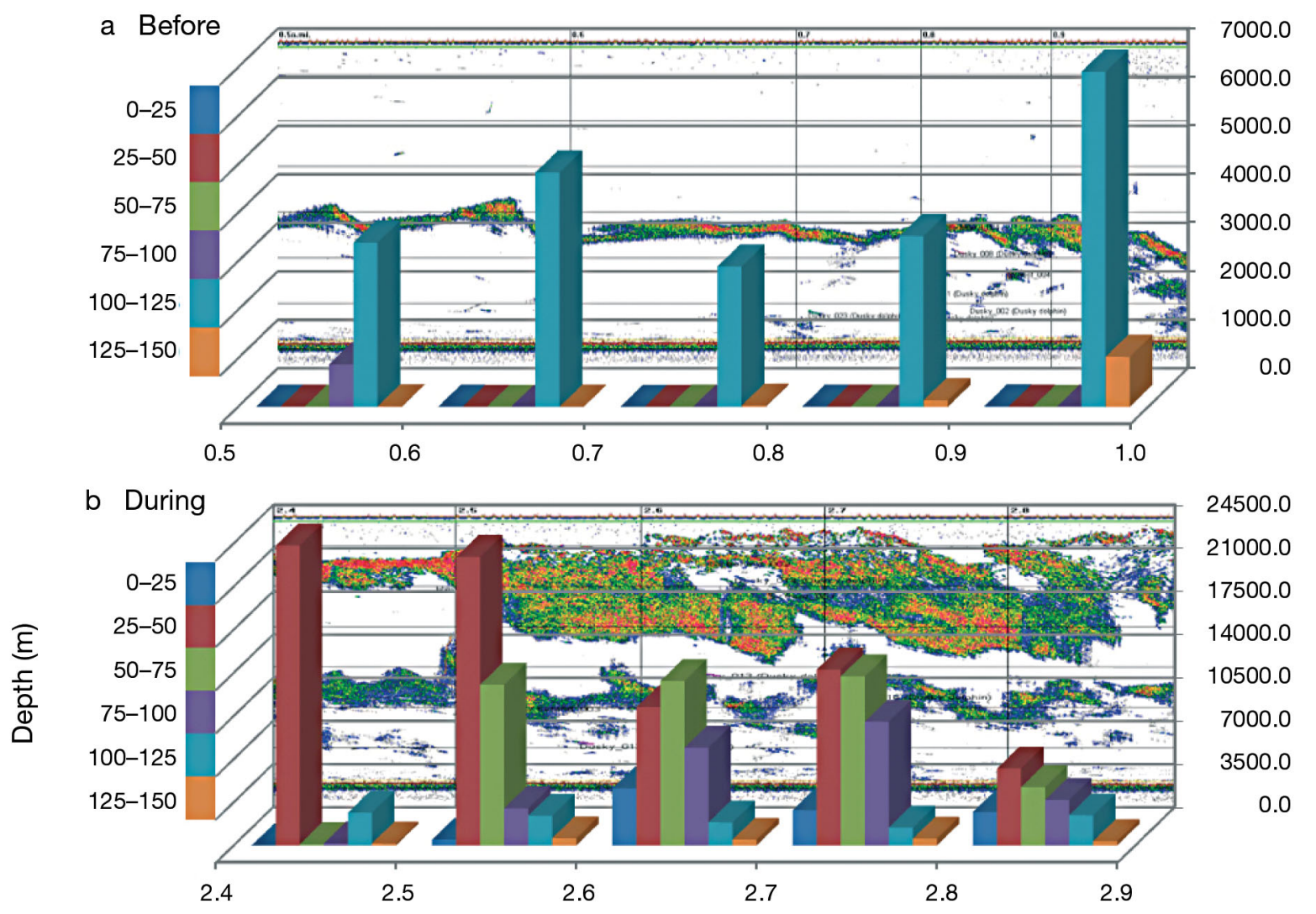

24500.0

21000.0

17500.0

14000.0

10500.0

7000.0

3500.0

0.0

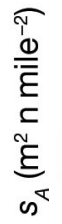

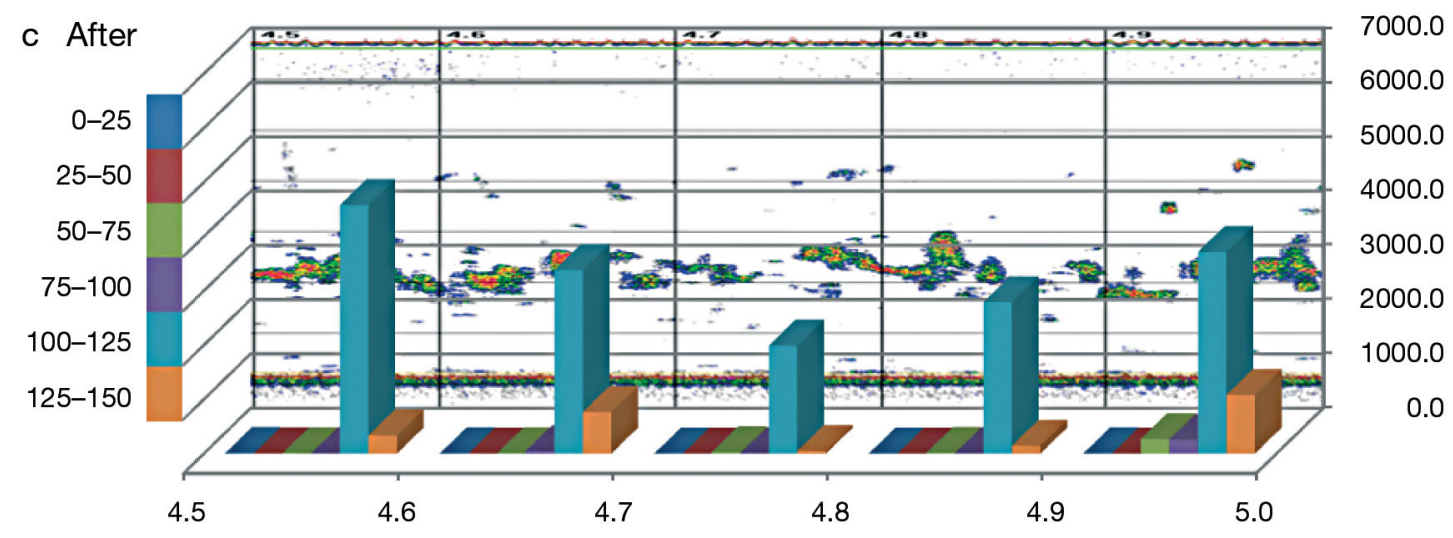

Distance (nautical miles)

Fig. 5. Trachurus capensis. Example of Sv (dB) echograms (back panel) showing Cape horse mackerel (a) before, (b) during and

(c) after attacks by dusky dolphins. Histograms show the distribution of total $s_{A}$ (right $y$-axis) by depth intervals (left $y$-axis)

Table 2. Trachurus capensis. Predator response events $(\mathrm{n}=54, \sim 0.45$ events $\mathrm{min}^{-1}$ ) in attacked schools with corresponding depths and packing density ranges. See 'Materials and methods: Predator response reactions' for a description of each behaviour

\begin{tabular}{|c|c|c|c|c|c|}
\hline \multirow{2}{*}{$\begin{array}{l}\text { School } \\
\text { response }\end{array}$} & \multirow{2}{*}{$\begin{array}{l}\text { No. of } \\
\text { obs. }\end{array}$} & \multicolumn{2}{|c|}{$\longrightarrow$ Depth $(\mathrm{m}) \longrightarrow$} & \multicolumn{2}{|c|}{ — Density (fish $\mathrm{m}^{-3}$ ) } \\
\hline & & Min.-Max. & Mean \pm SD & Min.-Max. & Mean \pm SD \\
\hline & 21 & ? & & 2.6 & .48 \\
\hline $\mathrm{Spl}$ & 19 & $47-1$ & 113 & 0.3 & .23 \\
\hline Bend & 10 & $40-125$ & 98.9 & $1.10-3.12$ & $1.92 \pm 1.06$ \\
\hline Hourglass & 4 & $66-89$ & $78.5 \pm 9.7$ & $0.71-1.10$ & $0.96 \pm 0.17$ \\
\hline
\end{tabular}

near the surface and then launch direct, coordinated attacks into the densely packed schools, is consistent with recent studies on cetacean hunting techniques (Nøttestad \& Axelsen 1999, Vaughn et al. 2010). Our finding that the dolphins deliberately herded the horse mackerel towards the surface was supported by 3D traces of individual dolphins that showed the 


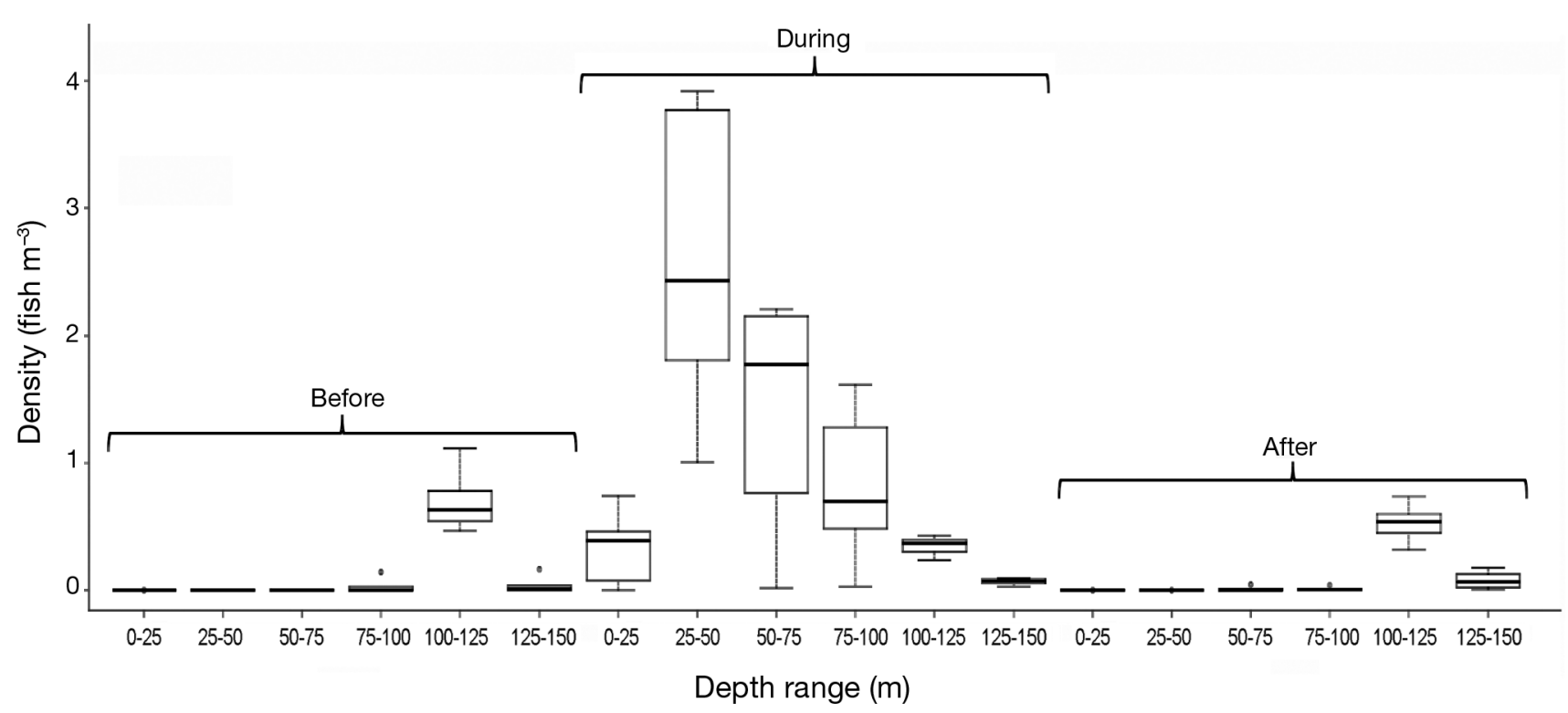

Fig. 6. Trachurus capensis. Cape horse mackerel volume packing densities (fish $\mathrm{m}^{-3}$ ) by depth before, during and after attacks by dusky dolphins. Lines: median value; boxes: $25 \%$ quartiles; whiskers: minimum and maximum values; dots: outliers $>2 \times$ upper quartile value)

Table 3. Trachurus capensis. Acoustic volume (Sv) densities and corresponding packing densities for random subsamples of unattacked and attacked schools

\begin{tabular}{|c|c|c|c|c|c|c|c|}
\hline \multirow[t]{2}{*}{ School state } & \multirow[t]{2}{*}{$\mathrm{n}$} & \multicolumn{3}{|c|}{ Density (fish $\mathrm{m}^{-3}$ ) } & \multirow[b]{2}{*}{ Min. } & \multirow[b]{2}{*}{ Max. } & \multirow{2}{*}{$\mathrm{Sv}(\mathrm{dB}) \overline{\text { Mean }(95 \% \mathrm{CI})}$} \\
\hline & & Min. & Max. & Mean $\pm \mathrm{SD}$ & & & \\
\hline Unattacked & 5 & 1.15 & 3.02 & $1.91 \pm 0.76$ & -51.77 & -47.59 & $-49.57(-51.46$ to -48.26$)$ \\
\hline Attacked & 5 & 5.90 & 12.50 & $8.77 \pm 2.71$ & -44.68 & -41.43 & $-42.96(-46.98$ to -40.90$)$ \\
\hline
\end{tabular}

dolphins encircling underneath the horse mackerel aggregations (Fig. 3). Dusky dolphins are also known to lift their prey to the surface before feeding as has been shown in documentary films (National Geographic Society 1999). Killer whales Orcinus orca have been observed to dive down to a maximum of $180 \mathrm{~m}$ depth in order to lift aggregations of Atlantic herring Clupea harengus (Nøttestad \& Similä 2001, Nøttestad et al. 2002b), and Nøttestad et al. (2002a) proposed a maximum diving depth of $200 \mathrm{~m}$ for fin whales Balaenoptera physalis. The present study is, however, the first to document that a much smaller odontocete, the dusky dolphin, may dive deeper than $150 \mathrm{~m}$ and lift their prey towards the surface, no doubt with considerable energetic efforts.

In the present study, dusky dolphins were observed to attack their prey 54 times in $2 \mathrm{~h}$, corresponding to an average observed attack rate of 0.45 events $\mathrm{min}^{-1}$. This is considerably higher than attack rates reported for fin whales attacking Atlantic herring (0.12 events $\mathrm{min}^{-1}$ ) (Nøttestad et al. 2002a) and also for killer whales attacking Atlantic herring (0.26 events min $^{-1}$ ) (Nøttestad \& Axelsen 1999), while it was lower than attack rates found for diving puffins Fratercula arctica attack- ing juvenile Atlantic herring (1.48 events $\left.\mathrm{min}^{-1}\right)$ (Axelsen et al. 2001). However, all those studies used multi-beam sonar with a much higher spatial resolution than the split-beam vertical echosounder used in the present study, and the actual event rate in the present study is likely to have been even higher.

Large predators bursting into fish schools cause individual fish to try to escape from the predators (Pitcher \& Wyche 1983, Axelsen et al. 2001), while the fish attempts to maintain a minimum approach distance of approximately 15 body lengths (Pitcher \& Wyche 1983), which in turn will lead to predator response reactions at the school level as seen in Table 2 . The horse mackerel aggregation under attack in the present study divided into 2 stable, vertically separated components (Axelsen et al. 2000). The dolphins then forced the fish from the deep towards the surface at high swimming speed, similar to that reported in other studies of dolphins attacking pelagic fish (Nøttestad \& Similä 2001, Nøttestad et al. 2002b). In the present study, the dolphins spent $63 \%$ of the time swimming underneath the school and only $37 \%$ of the time swimming above the horse mackerel aggregations, supporting the observation that the dolphins deliberately forced their prey towards the surface and kept them 

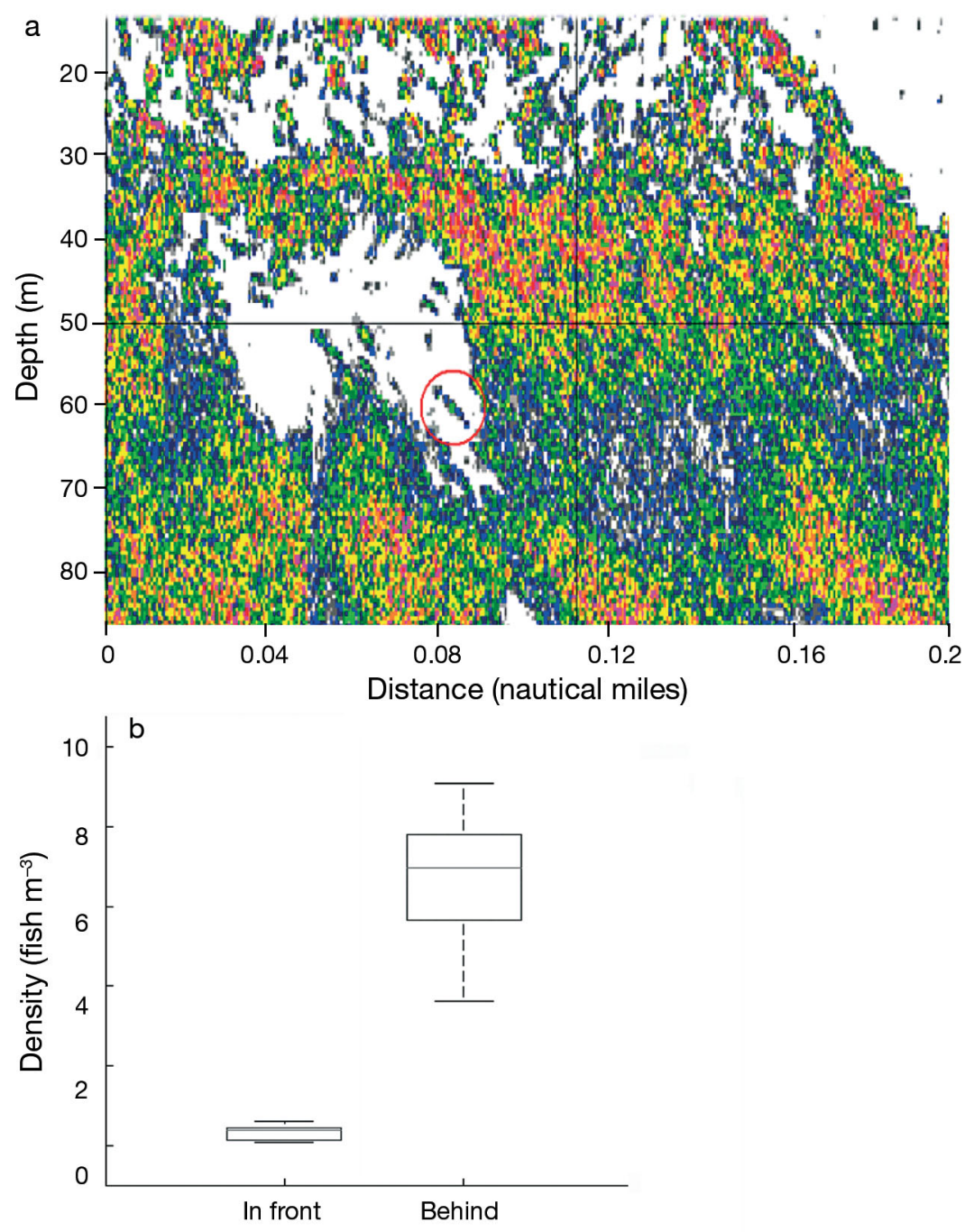

Fig. 7. Trachurus capensis. (a) Sv (dB) echogram subsection showing a typical 'Vacuole' formation caused by the intrusion of a dusky dolphin (encircled) into a Cape horse mackerel school and (b) volume densities (fish $\mathrm{m}^{-3}$ ) recorded immediately in front of and behind the dolphin, illustrating the fountain effect (Hall et al. 1986). Box plot symbols as in Fig. 6

from returning to deeper waters (Similä \& Ugarte 1993). The horse mackerel response observed in the present study was to aggregate in much denser and more synchronized aggregations (Nøttestad \& Axelsen 1999, Axelsen et al. 2001). The densities of the Cape horse mackerel we reported changed significantly in the periods before $\left(0.4\right.$ fish $\left.\mathrm{m}^{-3}\right)$, during $\left(2.0\right.$ fish $\left.\mathrm{m}^{-3}\right)$ and after $\left(0.3\right.$ fish $\left.\mathrm{m}^{-3}\right)$ the dolphin attacks, and unattacked schools had significantly lower densities compared with attacked schools, which conforms with the study by Nøttestad \& Axelsen (1999) and model simulations (Vabø \& Nøttestad 1997).

The dolphins attacked at high speeds, with a maximum recorded burst speed of $9.9 \mathrm{~m} \mathrm{~s}^{-1}$. The average attack speed was $3.4 \mathrm{~m} \mathrm{~s}^{-1}$, whereas the overall average swimming speed was only $1.4 \mathrm{~m} \mathrm{~s}^{-1}$. The attack swimming speeds and diving depths recorded here indicate that dolphins spend considerable energy on attacking their prey, suggesting that it was necessary for the dolphins to deliberately herd the horse mackerel towards the surface, pack them into 'tight balls' and keep them near the surface to feed on them (Würsig \& Würsig 1980, Wells et al. 1999, Nøttestad et al. 2002b). This is supported by the higher densities recorded for attacked than for unattacked schools (Table 2), which conforms with the findings of Nøttestad et al. (2002a,b) for example.

The relatively low oxygen levels $(<1 \mathrm{ml}$ $\mathrm{l}^{-1}$ ) found below $100 \mathrm{~m}$ depth may have restricted the horse mackerel from diving deeper while under attack at depth. However, Cape horse mackerel are reported to tolerate oxygen levels $<1 \mathrm{ml}^{-1}$ (G. Bauleth-D'Almeida unpubl. data), and the presence of dolphins below the schools at depth, combined with their active encircling behaviour, suggest that downward movements by the horse mackerel was not limited by oxygen levels here. The large vertical Hourglass formation found for horse mackerel here is similar to those reported for Atlantic herring (Axelsen et al. 2001). This could be an adaptation in 'trapped' schooling fish that enables them an escape passage to more secure locations - in the case of the present study towards deeper, darker waters - that dolphins attempted to counteract by encircling underneath the schools (Nøttestad \& Axelsen 1999, Nøttestad et al. 2002b, Vaughn et al. 2010).

The dusky dolphins maintained a dense aggregation of fish in the upper $50 \mathrm{~m}$ of the water column for a prolonged period of time ( 50 min). The Vacuole school responses, leading to empty spaces forming around the predators, were equivalent to responses in adult Atlantic herring to attacks from killer whales (Similä \& Ugarte 1993, Nøttestad \& Axelsen 1999) and in juvenile Atlantic herring to attacks from puffins (Axelsen et al. 2001) off northern Norway. In the present study, prey avoidance reactions caused significantly lower fish densities in front of the attacking predators $(0.33 \pm$ 0.17 fish $\left.\mathrm{m}^{-3}\right)$ than behind them $\left(6.65 \pm 1.76\right.$ fish $\left.^{-3}\right)$. Fish in aggregations generally maintain a minimum approach distance to predators of about 15 body lengths (Pitcher \& Wyche 1983) and high density regions shift- 
ing within schools, or density propagation (Axelsen et al. 2001), are thus a natural consequence of individual fish avoiding predators (Breder 1954, Hamilton 1971, Pitcher \& Wyche 1983, Axelsen et al. 2001). The reduced densities in front of and the increased densities behind the predators as they burst into the school are indicative of fish moving away from the predator and rejoining behind them, i.e. the fountain effect (Hall et al. 1986). Vacuole formation around attacking dolphins observed in large aggregations in the present study is supported by other studies (Vabø \& Nøttestad 1997. Nøttestad \& Axelsen 1999, Axelsen et al. 2001) despite the limited spatial resolution offered by the conventional single-beam (split-beam) we used. The evolution of swimming speed within the dusky dolphin traces observed in the present study suggests that rapid accelerations were followed by gliding behaviour. This is consistent with studies of trained Tursiops (Williams et al. 1999), in which acceleration followed by gliding at depth was put forward as a strategy to conserve energy.

The in situ TS measurements reported here (range: -22.7 to $-39.9 \mathrm{~dB}$ ) are consistent with Au et al. (2007), who measured the TS of a trained bottlenose dolphin Tursiops truncatus under controlled conditions to range from -40 to $-26 \mathrm{~dB}$. Cetacean TS should, however, be explored in more detail to establish length dependencies and interspecies variation. Multifrequency target triangulation (Pedersen et al. 2004) may be one approach to help to identify and isolate dolphin targets and, thus, explain observed variability.

The results reported in the present study demonstrate the power of acoustic target tracking as a tool for mapping underwater movements of marine mammals, and we believe that advanced acoustic methods combined with visual observations and underwater video recording have the potential to improve our understanding of marine mammal behaviour considerably (Hedgepeth et al. 2000).

Acknowledgements. This work was supported by the Benguela Environment Fisheries Interaction Programme (BENEFIT), now the Benguela Current Commission (BCC) and partly funded by the Dr. Fridtjof Nansen Programme and Norwegian Agency for Development Coorperation. The authors acknowledge the support of officers and crew of the RV 'Dr. Fridtjof Nansen' and fellow researchers and technicians at the National Marine Information and Research Centre (NatMIRC) in Swakopmund, the National Institute of Fisheries Research (INIP) in Luanda, the Institute of Marine Research (IMR) in Bergen and the Research Council of Norway. Many thanks for the revision of the manuscript at different stages go to Prof. E. Ona and Dr. L. Calise, Institute of Marine Research, Bergen, and Prof. A. S. Brierley and Dr. M. Cox, Pelagic Ecology Research Group, University of St Andrews. A special thank you is expressed to Dr. M. Wilson, Myriax Software, for the constant technical support and to Prof. R. Groppali and Prof. S. Frugis, Università degli Studi di Pavia, from M.B. for their constant support.

\section{LITERATURE CITED}

Aguayo A, Bernal R, Olavarria C, Vallejos V, Hucker R (1998) Cetacean observations carried out between Valparaiso and Easter Island, Chile, in the winters of 1993, 1994 and 1995. Rev Biol Mar Oceanogr 33:101-123

Au WWL (1996) Acoustic reflectivity of a dolphin. J Acoust Soc Am 99:3844-3848

$\mathrm{Au}$ WWL, Houser DS, Dankiewicz LA (2007) Acoustic backscatter from a diving dolphin. J Acoust Soc Am 121:3106

> Axelsen BE, Nøttestad L, Fernö A, Johannessen A, Misund OA (2000) 'Await' in the pelagic: dynamic trade-off between reproduction and survival within a herring school splitting vertically during spawning. Mar Ecol Prog Ser 205:259-269

> Axelsen BE, Anker-Nilssen T, Fossum P, Kvamme C, Nøttestad L (2001) Pretty patterns but a simple strategy: predator-prey interactions between juvenile herring and Atlantic puffins observed with multi-beam sonar. Can J Zool 79:1586-1596

Axelsen BE, Krakstad JO, Bauleth-D'Almeida G (2004) Aggregation dynamics and behaviour of the Cape horse Mackerel (Trachurus capensis) in the Northern Benguela - implication for acoustic abundance estimation. In: Sumaila UR, Boyer D, Skogen MD, Steinshamn SI (eds) Namibia's fisheries. Eburon Academic Publishers, Delft, p 135-164

Benoit-Bird KJ, Würsig B, McFadden CJ (2004) Dusky dolphin (Lagenorhynchus obscurus) foraging in two different habitats: active acoustic detection of dolphins and their prey. Mar Mamm Sci 20:215-231

Bernasconi M, Patel R, Nøttestad L, Knudsen FR, Brierley AS (2009) Use of active sonar for cetacean conservation and behavioural ecology studies: a paradox? In: Capus C, Dible S, Dobbins P, Flint J and others (eds) Proceedings of the Institute of Acoustics 5th International Conference on BioAcoustics, Holywell Park, Loughborough University, 31 Mar-2 Apr 2009, p 112-118

Beyer JE (1995) Functional heterogeneity: using the interrupted Poisson process (IPP) model unit in addressing how food aggregation may affect fish ration. ICES CM 1995/ Q:10, Copenhagen

Boyer DC, Hampton I (2001) An overview of the living marine resources of Namibia. S Afr J Mar Sci 23:5-35

Breder CM Jr (1954) Equations descriptive of fish schools and other animal aggregations. Ecology 35:361-370

> Clark CW, Mangel M (1984) Foraging and flocking strategies: information in an uncertain environment. Am Nat 123: 626-641

Foote KG (1987) Fish target strengths for use in echo integrator surveys. J Acoust Soc Am 82:981-987

> Hall SJ, Wardle CS, MacLennan DN (1986) Predator evasion in a fish school: test of a model for the fountain effect. Mar Biol 91:143-148

> Hamilton WD (1971) Geometry of the selfish herd. J Theor Biol 31:295-311

> Hedgepeth JB, Fuhriman D, Cronkite GMW, Xie Y, Mulligan TJ (2000) A tracking transducer for following fish movement in shallow water and at close range. Aquat Living Resour 13:305-311

Jefferson TA, Webber MA, Pitman RL (2008) Marine mammals of the world: a comprehensive guide to their identification. Academic Press/Elsevier, London

> Kenney RD, Scott GP, Thompson TJ, Winn HE (1997) Estimates of prey consumption and trophic impacts of cetaceans in the USA northeast continental shelf ecosystem. J Northwest Atl Fish Sci 22:155-171 
Love RH (1973) Target strengths of humpack whales Megaptera novaeangliae. J Acoust Soc Am 54:1312-1315

Lucifredi I, Stein PJ (2007) Gray whale target strength measurements and the analysis of the backscattered response. J Acoust Soc Am 121:1383-1391

MacLennan DN, Fernandes PG, Dalen J (2002) A consistent approach to definitions and symbols in fisheries acoustics. ICES J Mar Sci 59:365-369

Miller JH, Potter DC, Weber T, Felix J (1999) The target strength of the northern right whale (Eubalaena glacialis). J Acoust Soc Am 105:992 (Abstract)

National Geographic Society (1999) Dolphins: 'the wild side'. Warner Home Video, Burbank, CA

Nøttestad L, Axelsen BE (1999) Herring schooling manoeuvres in response to killer whale attacks. Can J Zool 77: $1540-1546$

Nøttestad L, Similä T (2001) Killer whales attacking schooling fish: Why force herring from deep water to the surface? Mar Mamm Sci 17:343-352

Nøttestad L, Fernö A, Mackinson S, Pitcher T, Misund OA (2002a) How whales influence herring school dynamics in a cold-front area of the Norwegian Sea. ICES J Mar Sci 59:393-400

Nøttestad L, Fernö A, Axelsen BE (2002b) Digging in the deep: killer whales' advance hunting tactic. Polar Biol 25: 939-941

Pearre S Jr (2003) Eat and run? The hunger/satiation hypothesis in vertical migration: history, evidence and consequences. Biol Rev Camb Philos Soc 78:1-79

Pedersen G, Korneliussen RJ, Ona E (2004) The relative frequency response, as derived from individually separated targets on cod, saithe and Norway pout. ICES CM 2004/ R:16, Copenhagen

Peña HE (2004) In situ target strength measurements of Chilean jack mackerel (Trachurus symmetricus murphyi, Nicholos) using a commercial vessel with split-beam echo sounder. MPhil thesis, University of Bergen

Perrin WF, Würsig B, Thewissen JCM (2002) Encyclopedia of marine mammals. Academic Press, San Diego CA

Pillar SC, Barrange M (1998) Feeding habits, daily ration and vertical migration of Cape horse mackerel south of South Africa. S Afr J Mar Sci 19:263-274

Pitcher TJ, Parrish JK (1993) Functions of shoaling behaviour in teleosts. In: Pitcher TJ (ed) The behaviour of teleost fishes, 2nd edn. Chapman \& Hall, London, p 364-439

Pitcher TJ, Wyche CJ (1983) Predator avoidance behaviour of sand-eel schools seldom split. In: Noakes DLG, Linquist BG, Helfman GS, Wards JA (eds) Predators and prey in fishes. Dr. W. Junk, The Hague, p 193-204

Shannon LV (1985) The Benguela ecosystem. 1. Evolution of the Benguela, physical features and processes. Oceanogr Marine Biol Annu Rev 23:105-182

Shannon LV, Nelson G (1996) The Benguela: large scale features and processes and system variability. In: Wefer $G$,

Editorial responsibility: Hans Heinrich Janssen, Oldendorf/Luhe, Germany
Berger WH, Siedler G, Webb DJ (eds) The South Atlantic: present and past circulation. Springer-Verlag, Berlin, p 163-210

Shannon LV, O'Toole MJ (2003) Sustainability of the Benguela: ex Africa simper aliquid novi. In: Hempel G, Sherman K (eds) Large marine ecosystems of the worldtrends in exploitation, protection and research. Elsevier, Amsterdam, p 227-253

Similä T (1997) Sonar observations of killer whales (Orcinus orca) feeding on herring schools. Aquat Mamm 23: 119-126

Similä T, Ugarte F (1993) Surface and underwater observations of cooperatively feeding killer whales in northern Norway. Can J Zool 71:1494-1499

Simmonds EJ, MacLennan DN (2005) Fisheries acoustics: theory and practice, 2nd edn. Blackwell Science, Oxford

> Thompson WB, Vertinsky I, Krebs JR (1974) The survival value of flocking in birds: a simulation model. J Anim Ecol 43:785-820

Vabø R, Nøttestad L (1997) An individual based model of fish school reactions: predicting antipredator behaviour as observed in nature. Fish Oceanogr 6:155-171

Van Waerebeek K, Würsig B (2009) Dusky dolphin (Lagenorhynchus obscurus). In: Perrin WF, Würsig BG, Thewissen JGM (eds) Encyclopedia of marine mammals, 2nd edn. Academic Press, San Diego, CA, p 335-338

Vaughn RL, Shelton DE, Timm LL, Watson LA, Würsig B (2007) Dusky dolphin (Lagenorhynchus obscurus) feeding tactics and multi-species associations. NZ J Mar Freshw Res 41:391-400

Vaughn RL, Würsig B, Packard J (2010) Dolphin prey herding: prey ball mobility relative to dolphin group and prey ball sizes, multispecies associates, and feeding duration. Mar Mamm Sci 26:213-225

Vaz Velho F, Axelsen BE, Barros P, Bauleth-D'Almeida G (2006) Identification of acoustic targets off Angola using General Discriminant Analysis. Afr J Mar Sci 28:525-533

Vaz Velho F, Barros P, Axelsen BE (2010) Day-night differences in Cunene horse mackerel (Trachurus trecae) acoustic relative densities off Angola. ICES J Mar Sci 67:1004-1009

Wells RS, Boness DJG, Rathbun B (1999) Behavior. In: Reynolds JE III, Rommel SA (eds) Biology of marine mammals. Smithsonian Institution Press, Washington, DC, p 324-422

Williams TM, Haun JE, Friedl WA (1999) The diving physiology of bottlenose dolphins (Tursiops truncatus) I. Balancing the demands of exercise for energy conservation at depth. J Exp Biol 202:2739-2748

Würsig B (1982) Radio tracking dusky porpoises in the South Atlantic. In: Mammals in the seas, Vol 4: small cetaceans, seals, sirenians and otters. FAO Adv Comm Experts Mar Resour Res, Rome, p 145-160

Würsig B, Würsig M (1980) Behaviour and ecology of the Dusky dolphin, Lagenorhynchus obscurus, in the South Atlantic. Fish Bull 77:871-890

Submitted: August 7, 2009; Accepted: February 2, 2011 Proofs received from author(s): April 27, 2011 